\title{
Growth and Yield Characteristics of Field-grown Limonium sinuatum (L.)
}

\author{
Brian E. Whipker and P. Allen Hammer' \\ Department of Horticulture, 1165 Horticulture Building, Purdue University, \\ West Lafayette, IN 47907-1165
}

Additional index words. annual statice, cut flower, dried flower

\begin{abstract}
Field studies were conducted on the potential of annual statice as an outdoor cutflower crop for the Midwestern United States. Data was collected on seven cultivars in 1989 and 42 in 1990. In 1989, total fresh stem weight, stem count, and average stem weight differed significantly among cultivars. Yellow cultivars had more stems harvested than the rose, apricot, and blue cultivars, but stems of the yellow cultivars weighed less. The number of stems harvested over time tended to be concentrated in the first 8 weeks after flowering begins. In 1990, the average stem fresh weight was significantly different among the apricot, blue, and rose cultivars, but the number of stems harvested was significantly different only between the blue and rose cultivars.
\end{abstract}

In recent years, there has been a revival of interest in producing field-grown cut flowers. The production of annual statice is of special interest because the flowers may be used either fresh or dried and are available in an assortment of colors.

There are many cultivars of annual statice. Although general cultural information for this crop is available (Nau, 1988; Sommers, 1984; Wallace, 1988), few studies describe the flowering habits and yield of the various cultivars. General yield ranges have been reported (Espinosa and Healy, 1988; Laushman, 1989; Semeniuk and Krizek, 1973), and limited cultivar comparisons have been made based on studies conducted in Florida (Wilfret and Harbaugh, 1978), Germany (Zimmer, 1982), and Maryland (Healy and Aker, 1988). Our objective was to evaluate the suitability of the many new, annual statice cultivars as outdoor cut-flower crops for the Midwestern United States and to compare their yield potential and flowering habits.

\section{Materials and Methods}

Field studies were conducted in 1989 and 1990 on the potential of statice as a fieldgrown, cut-flower crop. In 1989, seven cultivars were grown. Seeds were sown in a greenhouse in germination trays containing a fine spaghnum peat mix (Terra-Lite Plug Mix; Grace-Sierra, Allentown, Pa.) on 7 Apr. Two

$\overline{\text { Received for }}$ publication on 26 Aug. 1993. Accepted for publication 22 Dec. 1993. Purdue Univ. Expt. Station paper no. 13925. Support was provided by Purdue Univ. Agricultural Expt. Station funds. George Ball Seed Co, Harris-Moran Seed Co., Fred C. Gloeckner Seed Co,, Grimes Seed Co., and Sakata Seed Co. donated seeds, We gratefully acknowledge the technical assistance of Terri Kirk, Mel White, Brad Kitchen, and Gerald Fankhauser, The cost of publishing this paper was defrayed in part by the payment of page charges. Under postal regulations, this paper therefore must be hereby marked advertisement solely to indicate this fact. To whom reprint requests should be addressed. weeks later, the plants were transplanted into cell packs $(5.5 \times 5 \times 6$-cm cells $)$ using a 1 soil : 2 sphagnum peat $: 2$ perlite (by volume) mixture amended with $890 \mathrm{~g} \mathrm{Ca}\left(\mathrm{HO}_{2} \mathrm{PO}_{4}\right)_{2}, 593 \mathrm{~g}$ $\mathrm{KNO}_{3}, 593 \mathrm{~g} \mathrm{MgSO}_{4}, 4.75 \mathrm{~kg}$ ground limestone, and $74.2 \mathrm{~g}$ fritted trace elements no. 555 (Peters, Allentown, Pa.), all per cubic meter of mix. The plants were fertilized at each watering with $200 \mathrm{mg} \cdot$ liter $^{-1}$ each of $\mathrm{N}$ and $\mathrm{K}$ supplied from $367 \mathrm{mgNH}_{4} \mathrm{NO}_{3}$ and517 $\mathrm{mg} \mathrm{KNO}_{3}$ per liter, with $46 \mathrm{mg}$ P/liter supplied via $75 \%$ technical grade phosphoric acid in the irrigationsystem.

The plants were transplanted into the field at the Pinney-Purdue Agricultural Research Center in Wanatah, Ind., on 22 May. The soil was a Tracy sandy loam with $1.5 \%$ organic matter. The field had been plowed and disked before planting. Three replications of each cultivar were grown, and cultivars were randomly assigned within each of three blocks. The plots measured $1 \times 3 \mathrm{~m}$; they were covered with black plastic mulch, and a trickle irrigation pipe was placed under the plastic between two parallel rows of plants. Each replication contained 19 plants that were offset-planted (two parallel rows with $30 \mathrm{~cm}$ between plants and rows) in the 3-m-long plot. The plants were irrigated as needed and fertilized with $100 \mathrm{mg}$ of $20 \mathrm{~N} 4.4 \mathrm{P}-16.6 \mathrm{~K} / \mathrm{liter}$ through the trickle irrigation system during the first 3 weeks they were in the field. Weeds between plastic strips were controlled by cultivation using hand tools and a rototiller. Weekly barvesting began on 14 July when the plants first bloomed and ended on 9 Oct. when a killing frostterminatedflowerdevelopment. The number of stems, individual stem fresh weight, and stem length were recorded.

In 1990, 42 cultivars were evaluated: 19 blue, five apricot, and 18 rose. We used the same cultural practices as described for the study performed in 1989, except seeds were sown 18 Apr. and transplanted into the field 12 June. Harvesting started on 19 July and ended on 1Oct. At each harvest, the number of stems and total fresh weight per plot were recorded.
Average stem fresh weight was calculated at each harvest by dividing the total weight of stems harvested per cultivar plot by the stem count.

We performed an analysis of variance on the data by general linear model procedures (SAS Institute, 1985). Significantly different means were separated by least significant differences at $P \leq 0.05$. For 1989 data, all statice cultivars were analyzed together. Due to variations in the number of stems produced and stem size among the color groups in 1990, we analyzed data for each of the three color categories separately.

\section{Results and Discussion}

In 1989, there were significant variations among cultivars in the number of stems produced, average stem length, and average stem fresh weight (Table 1). The yellow cultivars, 'Fortress Yellow' and 'Gold Strike', produced more stems per plot, but they had a lower average stem fresh weight than blue cultivars. The blue and purple cultivars, which have a higher demand in the marketplace, produced fewer stems, but they were heavier.

There was a significant difference in average stem fresh weight for all cultivars over the harvest season (data not shown). Stem fresh weights increased up to the sixth harvest and then remained fairly constant until the end of the harvest period. Although the average stem fresh weight tended to remain constant during the weekly harvests, the corolla of the individual flowers was noticeably smaller in later harvests and reduced the quality of the stems cut later. For the yellow and rose cultivars, the number of stems cut over the harvest season was concentrated during the first 8 weeks of the harvest season (Fig. 1). The blue and apricot cultivars had a less concentrated harvest season. Stem length was not significantly affected over the harvesting periods. The flowering concentration during the first 8 weeks of harvest for the yellow and rose cultivars and the decreasing flower quality during the later harvests suggests that growers should schedule multiple plantings of statice to maximize yield and flower quality over the entire growing season.

Table 1. Average number of statice stems harvested annually, average stem length, and average stem fresh weight per plot of 19 plants, by cultivar, 1989.

\begin{tabular}{lccc}
\hline \hline Cultivar & $\begin{array}{c}\text { No. } \\
\text { stems }\end{array}$ & $\begin{array}{c}\text { Stem } \\
\text { length } \\
(\mathrm{cm})\end{array}$ & $\begin{array}{c}\text { Fresh } \\
\mathrm{wt} \\
(\mathrm{g})\end{array}$ \\
\hline Fortress Yellow & 658 & 49.9 & 14.2 \\
Gold Strike & 535 & 52.0 & 16.7 \\
Fortress Rose & 419 & 40.6 & 14.0 \\
Fortress Apricot & 253 & 45.7 & 16.7 \\
Market & & & \\
$\quad$ Growers Blue & 184 & 43.3 & 26.8 \\
Fortress Purple & 169 & 52.1 & 31.3 \\
Fortress & & & \\
$\quad$ Dark Blue & 151 & 49.6 & 33.8 \\
Significance & $* * *$ & $* * *$ & $* * *$ \\
LSD $_{0.05}$ & 12.8 & 4.1 & 2.7 \\
\hline$* * *$ Siging
\end{tabular}

\footnotetext{
${ }^{* * *}$ Significant at $P \leq 0.0001$.
} 
The same cultivars grown in both years produced fewer stems in 1990 than 1989. The number of 'Fortress Rose', 'Fortress Apricot', 'Market Growers Blue', and 'Fortress Dark Blue' stems produced per plot was $24.0 \%$, $52.8 \%, 53.5 \%$, and59.8\% lower, respectively, in 1990. Unseasonably cool weather in June and July 1990 seemed to slow plant development and may have contributed to the difference.

Five apricot statice cultivars were compared in 1990. There were significant cultivar differences in average stem fresh weight, but not in the number of stems harvested (Table 2). Over the harvest season, there were significant differences among the harvests for the number of stems (data not shown), with the distribution over time similar to 1989.

The 19 blue statice cultivars differed significantly in stem count (5-1 30) and average stem fresh weight (Table 2). The first harvest for blue statice cultivars was later than that for the other two colors. The number of stems harvested differed significantly among cultivars over the harvest season. For most blue cultivars, the number of stems harvested was still increasing when production was stopped because of a killing frost; however, the number of stems cut had peaked in some cultivars ('Compindi', 'Excellent Blue', 'Fortress Dark Blue', and 'Modra') as they had in 1989 (data not shown). There were also significant differences in average stem fresh weight among blue cultivars over the harvest season. The overall average stem fresh weight peaked by the third harvest and then decreased, but some cultivars ('Excellent Blue', 'Heavenly Blue', 'Pale Blue Strike', 'Sky Blue', 'Splendor Dark Blue', 'Splendor Light Blue', 'Splendor Midnight Blue', and 'Splendor Sky Blue') showed an increased average in stem fresh weight with later harvests.

The 18 rose statice cultivars differed in the average number of stems harvested (19-3 19) and average stem fresh weight (Table 2). The average number of stems harvested over the season followed the same pattern as in 1989, with the peak in number of stems occurring during the fifth harvest, but the average stem fresh weight remained constant after the third harvest (data not shown). In 1990, most of the rose cultivars followed a similar pattern for the number of weeks that stems were harvested. The exceptions were 'Turbo Peach' and 'Excellent Salmon Shades', which had a condensed flowering period with $>93 \%$ of the stems being cut during four harvests.

These data show significant differences among commercially available statice cultivars. Healy and Aker (1988) used similar cultivars in their study. They harvested more stems of 'Fortress Apricot' and 'Fortress Dark Blue' (35\% and 53\%, respectively) but had $44 \%$ fewer stems of 'Fortress Yellow' compared to our 1989 data. In studying optimal growing temperatures for statice, the number of 'American Beauty' and 'Midnight Blue' stems that we harvested per plant was similar to that harvested by Semeniuk and Krizek (1973) for plants grown under a high-temperature regime. In Semeniuk and Krizek's study, the high-temperature regime resulted in more cut stems of 'American Beauty', but lower yields for 'Midnight Blue'. With the variation in results obtained from the different locations, growers should be encouraged to plant cultivars that will maximize yield. The diversity in yield, color, and harvest season allows growers to select cultivars that have characteristics best suited to their market.

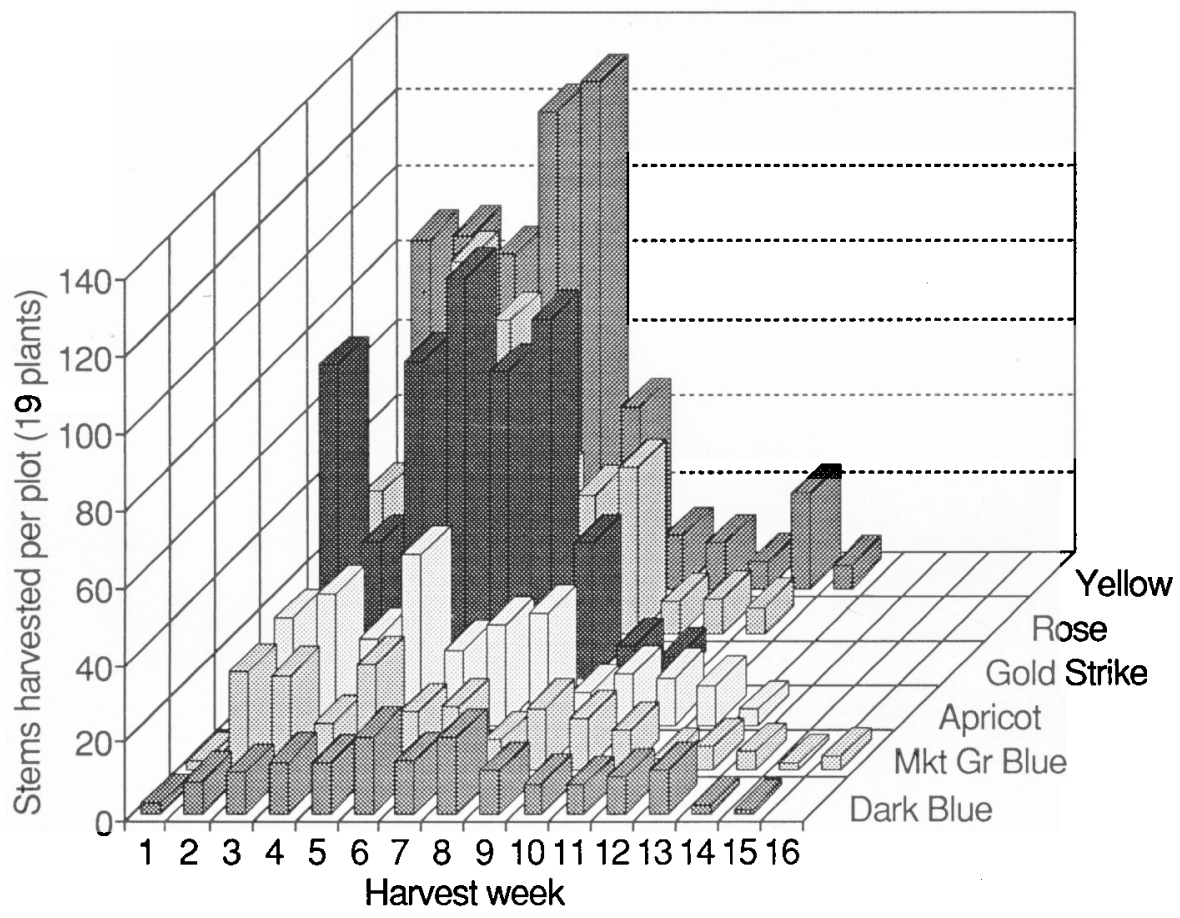

Fig. 1. Number of stems harvested weekly (week 1 began 14 July 1989) of six annual statice cultivars harvested per plot of 19 plants.
Table 2. Average number of statice stems harvested annually and average stem fresh weight per plot of 19 plants, by color and cultivar, 1990 .

\begin{tabular}{lccc}
\hline $\begin{array}{l}\text { Color and } \\
\text { cultivar }\end{array}$ & $\begin{array}{c}\text { Seed } \\
\text { source }^{z}\end{array}$ & $\begin{array}{c}\text { No. } \\
\text { stems }\end{array}$ & $\begin{array}{c}\text { Fresh } \\
\text { wt (g) }\end{array}$ \\
\hline Apricot & & & \\
Apricot Beauty & BA & 148 & 20 \\
Fortress Apricot & GL & 119 & 24 \\
Apricot & GR & 114 & 20 \\
Apricot & HM & 76 & 21 \\
Apricot & GL & 47 & 18 \\
Significance & & NS & $* *$ \\
LSD $_{0.05}$ & & --- & 4.7
\end{tabular}

Blue

Modra

Blue River

Excellent Blue

Compindi

Splendor

$\begin{array}{lll}\text { Midnight Blue } & \text { GL } & 93\end{array}$

Market

Growers Blue

Excellent

Light Blue

Heavenly Blue

Fortress

Dark Blue

Fortress

Heavenly Blue

Dark Blue

Charm

Splendor

Sky Blue

Sky Blue

Kamf Blue

Sunburst

Dark Blue

Splendor

Dark Blue

Midnight Blue

Pale Blue Strike

Sunburst

Light Blue

Significance

LSD $_{0.05}$

Rose

Fortress Rose

Turbo Peach

Excellent Rose

Shades

Market Rose

Excellent Salmon

Shades

American Beauty

GL $\quad 130 \quad 39$

GL 128

SK 122

GL $\quad 108$

35

GL $\quad 86$

SK $75 \quad 32$

GL $\quad 73 \quad 33$

GL $\quad 61 \quad 36$

GL $\quad 58 \quad 39$

GL $\quad 51 \quad 35$

GL $\quad 50 \quad 35$

HM $\quad 36 \quad 42$

GL $\quad 32 \quad 45$

BA $\quad 27 \quad 37$

GL $\quad 21 \quad 37$

GL $\quad 19 \quad 40$

GL $\quad 13 \quad 29$

GL $\quad 5 \quad 29$

3.8

3.0

GL $\quad 319 \quad 11$

GL $284 \quad 14$

SK $236 \quad 15$

GL $\quad 207 \quad 16$

SK $196 \quad 14$

GR $187 \quad 17$

Splendor

$\begin{array}{llll}\text { Carmine Rose } & \text { GL } & 169 & 19\end{array}$

Excellent Rose

Rose Charms

Rose Charms 320

GR 144

GL $\quad 115$

GL $\quad 109$

16

American

Beauty

Lady Rose

Roselights

Superb Rose

Rosea Splendens

Rose Strike

Splendor Rosea

Splendens

Sunburst Rose

Significance

GL $\quad 101 \quad 16$

GL $\quad 51 \quad 20$

GL $\quad 48 \quad 22$

HM $41 \quad 19$

GL $\quad 31 \quad 21$

GL $26 \quad 22$

GL $\quad 22 \quad 19$

$\begin{array}{ccc}\text { BA } & 19 & 18 \\ & * * * & * * *\end{array}$

$6.7 \quad 1.9$

BA = Ball Seed Co., West Chicago, Ill.; GL = Fred

C. Gloeckner, New York; GR = Grimes Seed Co., Smethport, Pa.; HM = Harris-Moran Seed Co., Rochester, N.Y.; SK = Sakata Seed Co., Salinas, Calif.

Ns, **, **** Nonsignificant or significant at $P \leq 0.01$ or 0.0001 , respectively. 


\section{Literature Cited}

Espinosa, I. and W. Healy. 1988, Cut flower production for statice, Horticulture Production, HE 141-88, Univ. of Maryland Coop. Ext. Serv.

Healy, W. and S. Aker. 1988. Cut flower field studies 1988. Horticulture Production, HE, Univ. of Maryland Coop. Ext. Serv.

Laushman, J. 1989. Cultural profile: Statice (Limonium sinuatum) gatherings. Cut Flower Quarterly Winter:6-7.
Nau, J. 1988. Cultural notes: Statice. GrowerTalks 52(2):12-13.

SAS Institute. 1985. SAS introductory guide. 3rd ed. SAS Institute, Cary, N.C.

Semeniuk, P. and D.T. Krizek. 1973. Influence of germination and growing temperature on flowering of six cultivars of annual statice (Limonium $\mathrm{CV}$ ). J. Amer. Soc. Hort. Sci. 98(2):140-142.

Sommers, C. 1984. Producing cut flowers outdoors for added profit. Florists' Rev. 174(4496):2227.
Wallace, M.E. 1988, Field culture of dried flowers, p. 189-192. In: Commercial field production of cut and dried flowers. Proc. Natl. Symp. Ctr. Alternative Crops and Products, Univ. of Minnesota, St. Paul.

Wilfret, G.J. and B.K. Harbaugh. 1978. Annual statice production guide. Inst. of Food and Agr. Sci., Univ. of Florida, Agr. Res. and Educ. Ctr., Bradenton.

Zimmer, K. 1982. Ertragsuntersuchungen an Limonium (Statice), Deutscher Gartenbau 36(45): 1882, 1884. 